\title{
GLL
}

Geomatics, Landmanagement and Landscape No. $1 \bullet 2019$, 45-56

\section{ANALYSIS OF CHANGES IN LAND COVER STRUCTURE USING RING-SHAPED POLYGONS OF EVALUATION, ON THE EXAMPLE OF SELECTED AREAS OF SLOVAKIA, POLAND AND THE CZECH REPUBLIC}

\author{
Agnieszka Wnęk, Dawid Kudas, Jozef Halva
}

\begin{abstract}
Summary
The objective of this paper is the assessment of the share of individual land cover categories in centric and ring-shaped evaluation polygons. In the analyses the data from the Corine Land Cover project for 2006 and 2012 were used. These data are available through the Urban Atlas. The basic spatial statistics concerning the land cover categories were determined. As a result of the analyses, information about land cover changes that took place over a period of 6 years was obtained, observed with increasing distance from the assumed reference point. An inference was also made regarding the possibility of determining the changes taking place in selected units in the period of 2006-2012.
\end{abstract}

Keywords

evaluation polygon $\bullet$ land cover $\bullet$ Corine Land Cover $\bullet$ spatial data

\section{Introduction}

According to the European Landscape Convention [2000], the landscape is understood as a fragment of space combining both natural phenomena and processes resulting from human activity. However, as noted by Degórski [2009], the dominant impact on landscape transformation results from the anthropogenic factor. Due to the changes taking place in the aspects of space and time, we are dealing with the multidimensional nature of the landscape, as well as the necessity to study the interrelations between its various elements [Degórski 2016]. Furthermore, both micro- and macrostructure are considered in landscape studies [Lipský 2000]. The microstructure of the landscape is composed of elements such as small areas, lines or objects, as well as their shapes, sizes, spatial arrangements, and interrelations. On the other land, the macrostructure of the landscape is the main subject of socio-economic research, and the macrostructure is understood as the share of different types of land use in the particular area, such as arable land, built-up areas, forests, etc. [Bičik et al. 2015]. 
In addition to the concept of landscape, the concepts of land use and land cover are also distinguished. The first one is understood as a reflection of human activity in the landscape through the actual use of space. Due to the constant variability of the surface area of particular types of land use, these changes should be monitored [Noszczyk 2018]. Land cover is defined as the occurrence of biophysical elements within the terrain [Regulation 2011, Bičik et al. 2015].

Continuous economic development determines an increase in the demand for finding locations that would accommodate various types of investment development. This contributes to changes in land cover and land use, and in many cases it negatively affects rational space management and the maintenance of proper spatial order. The main example of that is the intensification of development projects in suburban areas, especially near large cities [Tokarczyk-Dorociak et al. 2018]. Staszewska [2012] points out that the development of built environment in the suburban area is chaotic, and it may cause specific threats and losses in terms of spatial planning and spatial development. Moreover, Staszewska [2012] indicates the necessity to focus the research on the spatial structure, especially within suburban area. The socio-political transition, such as the transformation that took place after 1989 in the countries of Eastern Europe, also plays an important role in the changes in land use [Pazúr and Bolliger 2017, Cegielska et al. 2018]. Determining the direction and dynamics of changes in land cover and land use is a difficult but desirable task, especially in the context of supporting rational spatial management [Drzewiecki 2008]. From this point of view, it becomes legitimate to analyse the existing changes in the spatial structure, which will then serve to predict future trends therein. Knowledge about the direction of changes in land use and land cover of the given area may help prevent the negative effects of these changes, and thus contribute to the correct management of space and the preservation of proper spatial order.

However, the detection of changes taking place in the spatial structure requires the selection of an appropriate method for describing or measuring landscape features, and the availability of appropriate and comparable information in different periods of time [Antrop 1998]. One of the basic research tools used in the analysis of landscape structure and its changeability over time is provided by the geographical information systems (GIS) [Bender et al. 2005, Szewrański et al. 2017]. Currently, spatial data related to changes taking place in the landscape are collected and made available by geospatial services, and a wide range of different types of software facilitates the conduct of proper analyses. Commonly used data sources on the changes occurring in land cover and land use include layers developed as part of the Corine Land Cover project, and made available in a standardized manner through the Urban Atlas (UA) project [UA mapping guide 2006 and 2012]. These layers, with the appropriate use of GIS tools, provide much information global, but also local - about the changes occurring in space [Cegielska et al. 2017a, Pazúr and Bolliger 2017, Cegielska et al. 2018]. Information on the spatial changes in terms of investment projects can also be derived from the analysis of the topographic objects database in the scale of 1:10 000 (in short: BDOT10k) [Cegielska 
et al. 2017b]. Also historical maps and aerial photographs that illustrate changes in land cover and land use can provide cyclical and comprehensive information that facilitates modelling of historical and future changes in land use [Halva and Cyprich 2017, Schulp et al. 2019].

The aim of the research was to analyze the possibility of determining changes in land cover macrostructure in 2006-2012 on the example of selected three areas around the city of Nitra, Radom, and Olomouc, located in Slovakia, Poland and the Czech Republic, respectively. The selected areas, along with delimitation of the terrain in terms of land cover, were made available via the Urban Atlas in the form of a vector layer. An attempt was made to assess the usefulness of centric and ringshaped evaluation polygons for the study of changes in the area of the available land cover layers, which are characterized by significant complexity of borders. In particular, the selection of the geometrical centre of the boundary of the analysed area was verified, taken as the starting point for the construction of the evaluation polygons, rather than assuming the spatial dominant of the city, which is usually the result of historical conditions.

\section{Material and methods}

The Urban Atlas website provides high-quality spatial data on the land use and land cover for European cities inhabited by a minimum of 100 thousand people, as well as suburban areas. In this work, data for analyses for the years 2006 and 2012 (Fig. 1 and 2) were obtained from the Urban Atlas website [2018] in the form of vector layers containing areas around the cities of Nitra (designation area $\mathrm{N}$ ), Radom (designation area $\mathrm{R}$ ), and Olomouc (designation area $\mathrm{O}$ ). These cities are located in Slovakia, Poland and the Czech Republic, respectively. The range of the analysed vector layers in most cases does not reflect the administrative boundaries. The surface sizes of the analysed areas were $871 \mathrm{~km}^{2}, 680 \mathrm{~km}^{2}$ and $894 \mathrm{~km}^{2}$, respectively. The factor determining the choice of these areas was their similarity in terms of spatial features and similar proportions between individual classes of land cover. In all of the analysed areas, we are dealing with monocentric agglomerations.
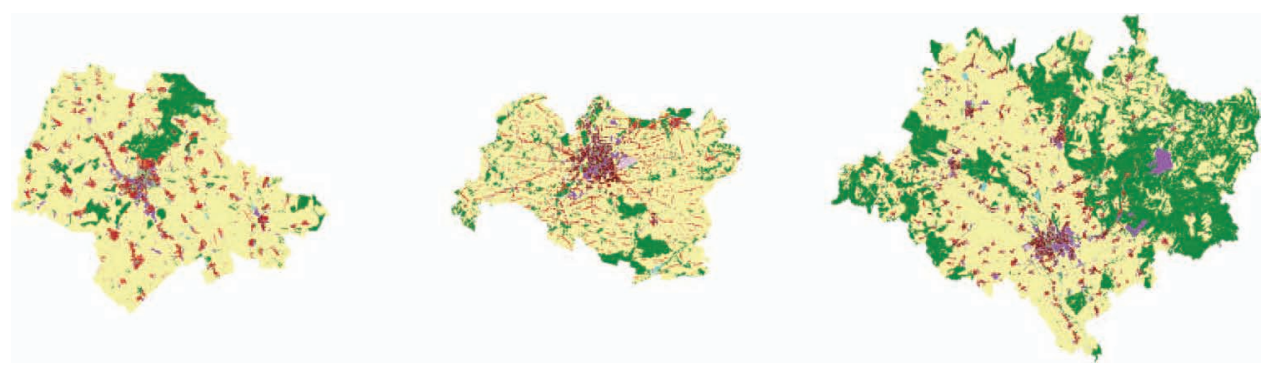

Fig. 1. Land cover layers from the UA for the year 2006, around the cities of Nitra, Radom, and Olomouc 

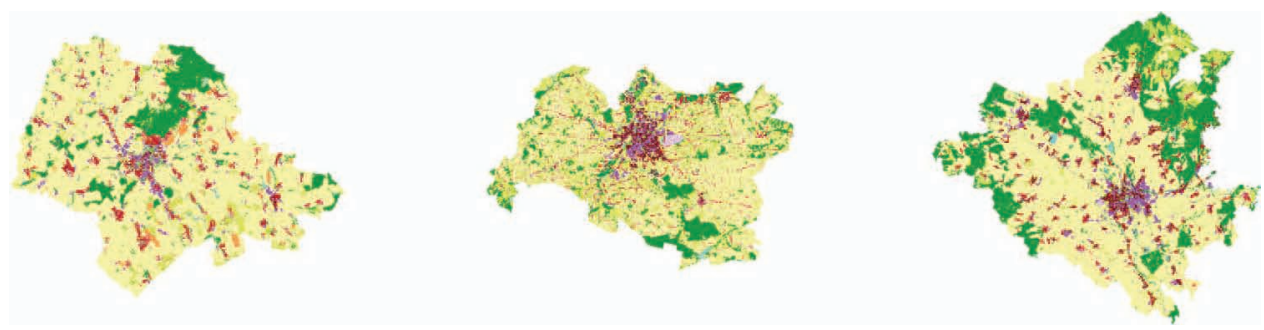

Fig. 2. Land cover layers from the UA for the year 2012, around the cities of Nitra, Radom, and Olomouc

The spatial distribution of the land cover categories (22 categories in 2006, and 29 categories in 2012), defined in the European Commission guidelines [2006], in the range of the available vector layers was subjected to quantitative assessment relative to the evaluation polygons. The analyses were carried out within the limits of the evaluation polygons, which are the vector product of the UA vector layer, and ring-shaped polygons, for which the difference between the length of the external and internal diameter was 2 kilometres. The geometric centre of the rings lay in the centroid of the boundaries of the vector layers made available by the UA. The beginning of the construction of ring-shaped polygons from the geometrical centre of the boundaries of the analysed layer, rather than from the geometric centre of the city, is justified as it optimises their position in relation to the entire analysed area (Fig. 3). In many cases, cities are not centrally located in terms of the extent of the available layers, which means that fitting the ring-shaped polygons would not be optimal. The analyses were carried out in the QGIS environment, which is a cross-platform, opensource geo-information software enabling, among others, geographic data management and spatial analysis. The boundaries of the areas made available in the UA around the cities of Nitra and Radom remained unchanged. However, in the case of the vector layer containing the area around the city of Olomouc, its range changed, which is the reason why only the common area for 2006 and 2012 was included in the analysis.

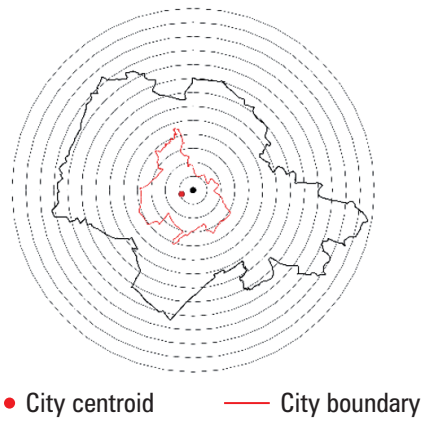

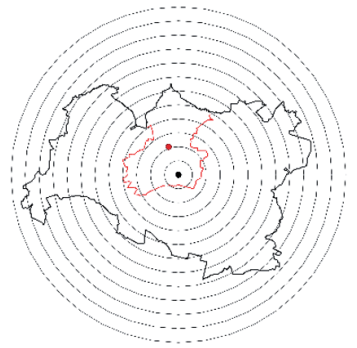

- Vector layer from UA centroid

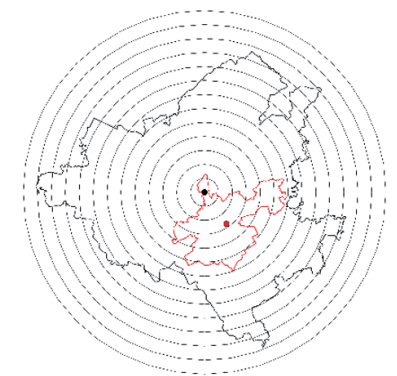

— Vector layer from UA boundary

Fig. 3. Configuration of ring-shaped polygons juxtaposed against the boundaries and centroid of the analysed layers from the UA, as well as the boundaries and centroids of Nitra, Radom, and Olomouc cities 
Within the product of each ring-shaped polygon and the area of the analysed layer, the areas of individual land cover categories for 2006 and 2012 were determined, followed by their percentage share in the area of each evaluation polygon. The use of percentage share is dictated by the variable surface area of individual evaluation polygons, as well as by the need to compare them. For each evaluation polygon, the share of investment (development) areas $A_{i, n}$ was determined (for the years 2006 and 2012, the total area of the categories: $11100,11210,11220,11230,11240,11300,12100,12210$, $12220,12230,12300,12400,13100,13300,13400$ and 14200) as well as the share of biologically active areas $A_{b, n}$ (for the year 2006, the total area of the categories 50000, $40000,30000,20,000$ and 14100 , and for the year 2012, the total area of the categories 50000, 40000, 33000, 32000, 31000, 25000, 24000, 23000, 22000, 21000 and 14100), according to the following formulas:

$$
\begin{gathered}
R_{i, n}=\frac{\sum A_{i, n}}{A_{n}} \cdot 100[\%] \\
R_{b, n}=\frac{\sum A_{b, n}}{A_{n}} \cdot 100[\%] \\
A_{n}=A_{U} \cap A_{R, n}
\end{gathered}
$$

where:

$A_{U} \quad$ - area of vector layer from UA,

$A_{R, n} \quad$ - surface of the $n$-number ring-shaped polygon,

$A_{n} \quad-$ area of the evaluation polygon (intersection of $A_{U}$ and $A_{R, n}$ ),

$\sum A_{i, n}$ - sum of the area of the categories accepted as investment (developed) areas in the $n$-number evaluation polygon,

$\sum A_{b, n}$ - sum of the area of the categories accepted as biologically active in the $n$-number evaluation polygon.

Within the area of each evaluation polygon, the ratio of the share of categories classified as investment areas to categories classified as biologically active areas was also determined:

$$
C_{R, n}=\frac{R_{i, n}}{R_{b, n}}
$$

Then, for each evaluation polygon, a coefficient showing the correlation between the surface size of land cover categories classified as investment areas, and those classified as biologically active areas was computed as follows:

$$
C_{s, n}=\sqrt{\frac{R_{i, n} \cdot R_{b, n}}{R_{i, n}^{2}+R_{b, n}^{2}}}
$$


Based on the calculated coefficients, the rate of change within the analysed areas was compared, along with the distance from the assumed reference point. The degree of similarity of the analysed areas due to the spatial structure of the land cover category in the corresponding evaluation polygons was also determined. A general analysis of the possibilities to determine changes that took place in the period from 2006 to 2012 within the boundaries of the examined layers was also conducted. To this end, a similarity measure of two vectors was used, based on the Hamming distance, which is the sum of the differences between numerical vectors of the same length. The similarity measure was determined according to the following formula:

$$
P_{U, n}=1-\frac{\sum h_{k, n}}{\sum k}
$$

where:

$\sum h_{k, n}$ - the Hamming distance in the $n$-th evaluation polygon between the percentage share of the surface area of particular land cover categories $k$ in the surface area of each evaluation polygon between 2006 and 2012, whereas:

$$
h_{k, n}=\left\{\begin{array}{l}
0, \text { if } v_{k, n(2006)}=v_{k, n(2012)} \\
1, \text { if } v_{k, n(2006)} \neq v_{k, n(2012)}
\end{array}\right.
$$

Due to the unequal number of land cover categories in 2006 and 2012, the additional categories, newly distinguished in 2012, were allocated to the corresponding categories from 2006.

\section{Results}

For the layers with the city of Nitra and Olomouc and the surrounding areas were created 13 ring-shaped polygons, and for layer with the city of Radom were 12 ringshaped polygons. Within the boundaries of the evaluation polygons, based on the ring-shaped polygons, the percentage share of individual land cover categories was determined, in accordance with the guidelines of the European Commission [2006], in the layers obtained from the UA for the years 2006 and 2012 (Figs 4-6).

The value of the share of particular land cover categories in the designated evaluation polygons does not provide clear information about the changes taking place along with the increasing distance from the geometric centre of the boundary of the analysed layer. Therefore, the ratio of the share of categories classified as investment areas to categories classified as biologically active areas $C_{R}$ was calculated (Fig. 7). However, the $C_{R}$ coefficient can take values from a broad range, therefore we have decided to also use the $\mathrm{C}_{S}$ standardized coefficient, which produces values from 0 to 1 (Fig. 8). 

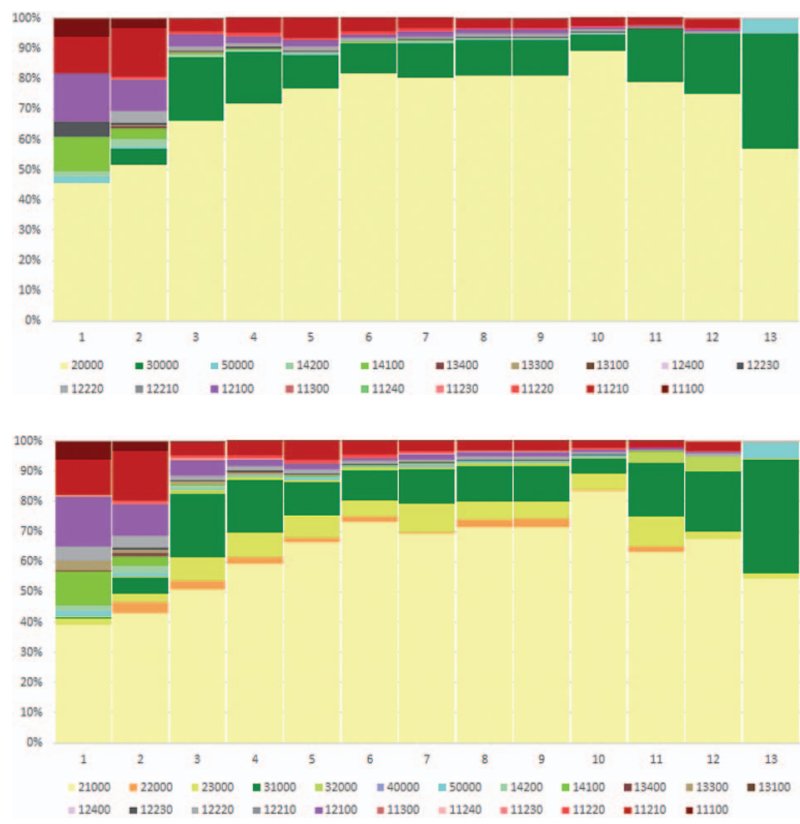

Fig. 4. Percentage share of land cover categories in the evaluation polygons in 2006 and 2012, for the layer including the city of Nitra
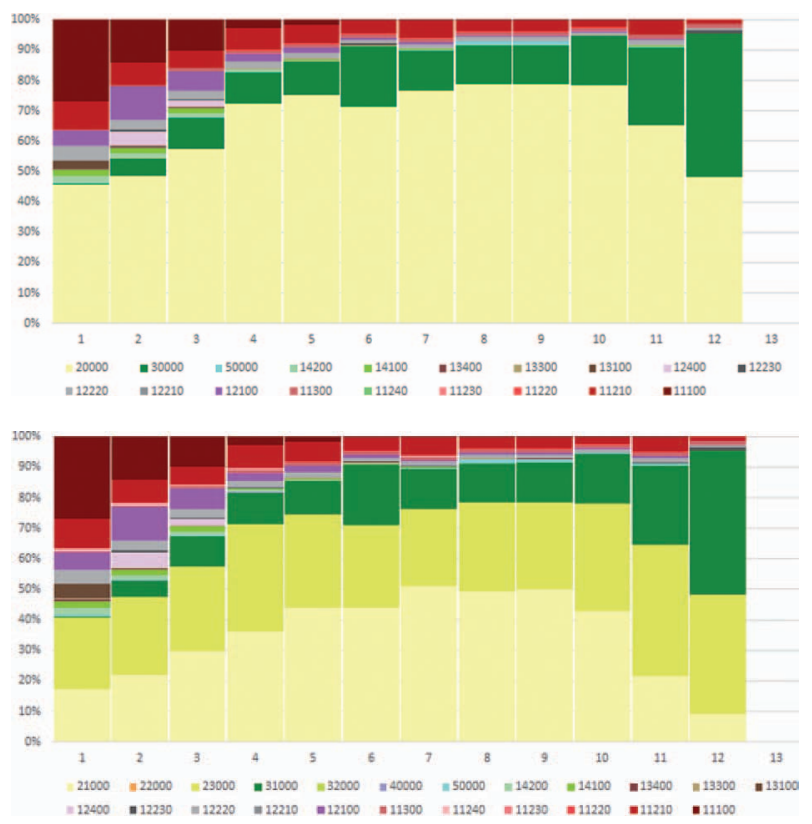

Fig. 5. Percentage share of land cover categories in the evaluation polygons in 2006 and 2012, for the layer including the city of Radom 

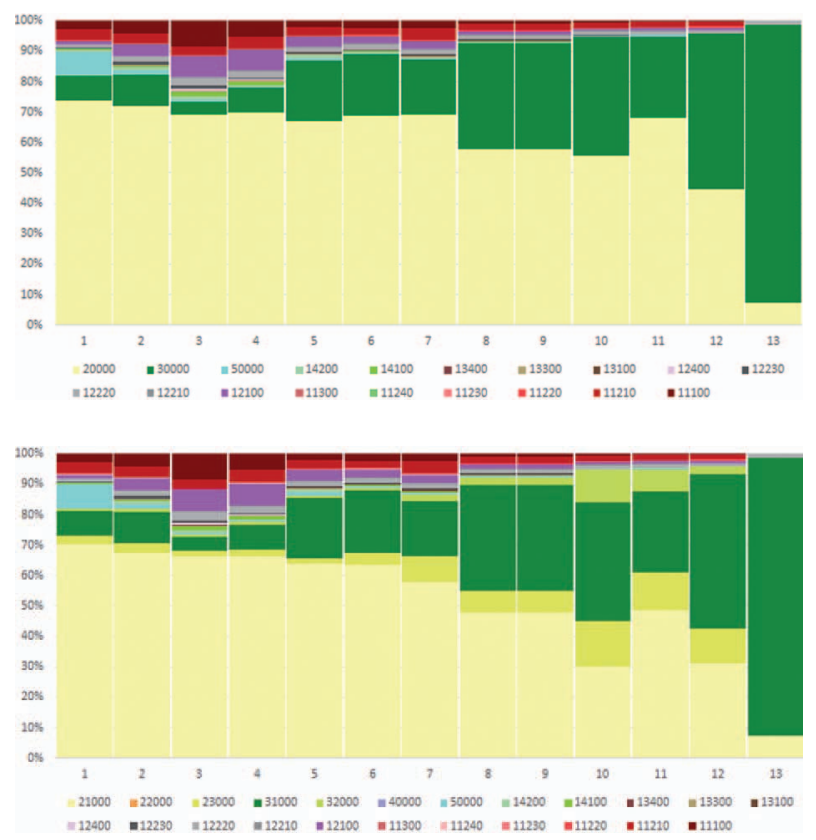

Fig. 6. Percentage share of land cover categories in the evaluation polygons in 2006 and 2012, for the layer including the city of Olomouc

As shown in Figures 7 and 8, the rate of change of $C_{R}$ and $C_{S}$ coefficients for the areas around Nitra and Radom is similar. Concentration of the land cover categories, which can be classified as anthropologically modified investment areas within the aforementioned regions, takes place in zones 1 and $2(0-2 \mathrm{~km}, 2-4 \mathrm{~km}$, respectively, from the geometric centre of the analysed area). The highest concentration of the investment (developed) areas category for the layer with the city of Olomouc, however, occurs in evaluation polygon 3 (4-6 km from the geometrical centre of the boundaries of the analysed area). An increase in the ratios is again observed in the evaluation polygon number $7(12-14 \mathrm{~km})$ - for the layer including the city of Radom as well as the layer including the city of Olomouc - and in the polygon number $11(20-22 \mathrm{~km})$ for the layer including the city of Radom. The observed difference in the degree of developed areas in individual evaluation polygons results from differences in the location of urban agglomerations relative to the boundaries of the analysed layers; and this is particularly evident in the case of the city of Olomouc, which is shifted southeast of the boundary of the analysed layer.

The similarity coefficient based on the Hamming distance calculated in accordance with formula (6), showing the degree of similarity between the percentage share of the surface area of particular land cover categories within the area of each evaluation polygon between 2006 and 2012, is illustrated in Figure 9. 


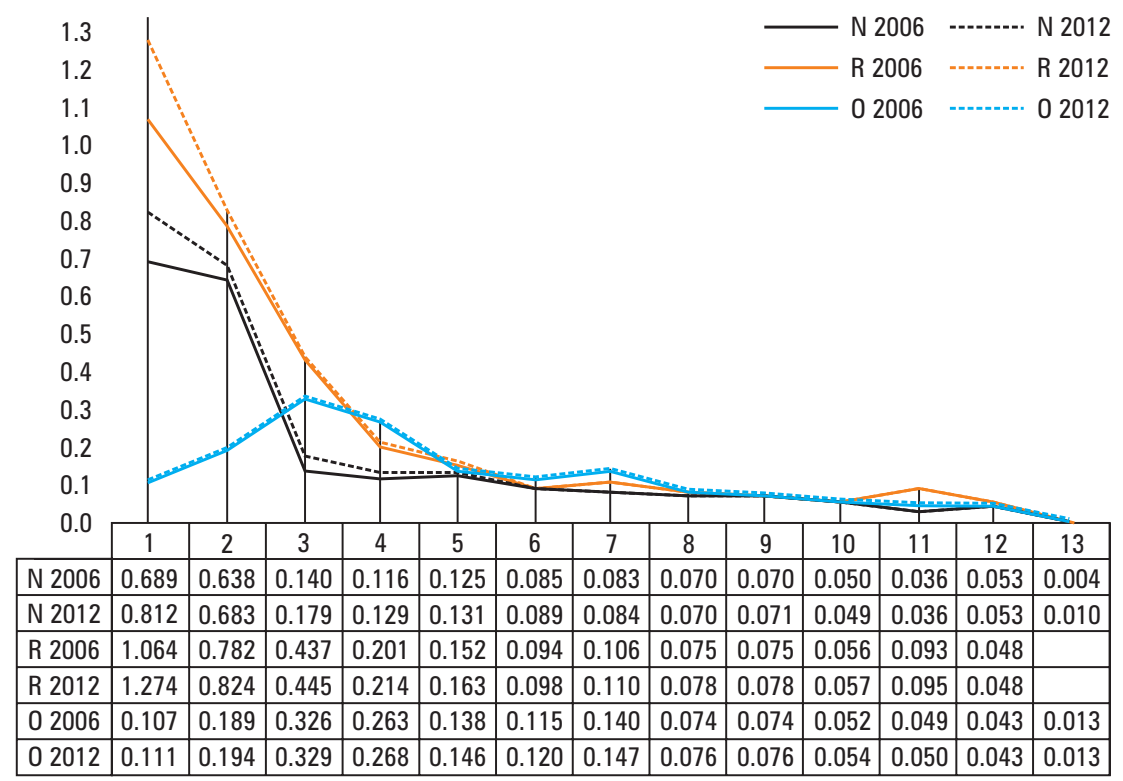

Fig. 7. Changes in the $C_{R}$ ratio within the boundaries of successive evaluation polygons for the layers including the cities of Nitra, Radom and Olomouc

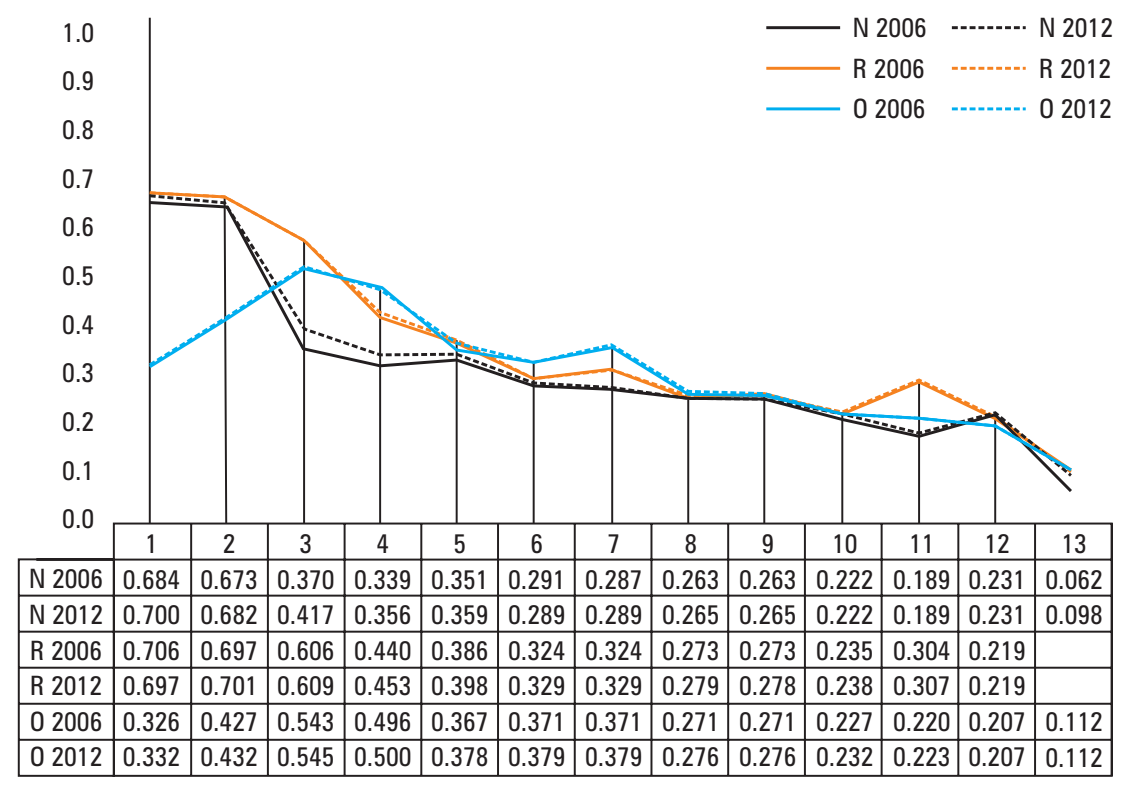

Fig. 8. Changes in the $C_{S}$ ratio within the boundaries of successive evaluation polygons for the layers including the cities of Nitra, Radom and Olomouc 


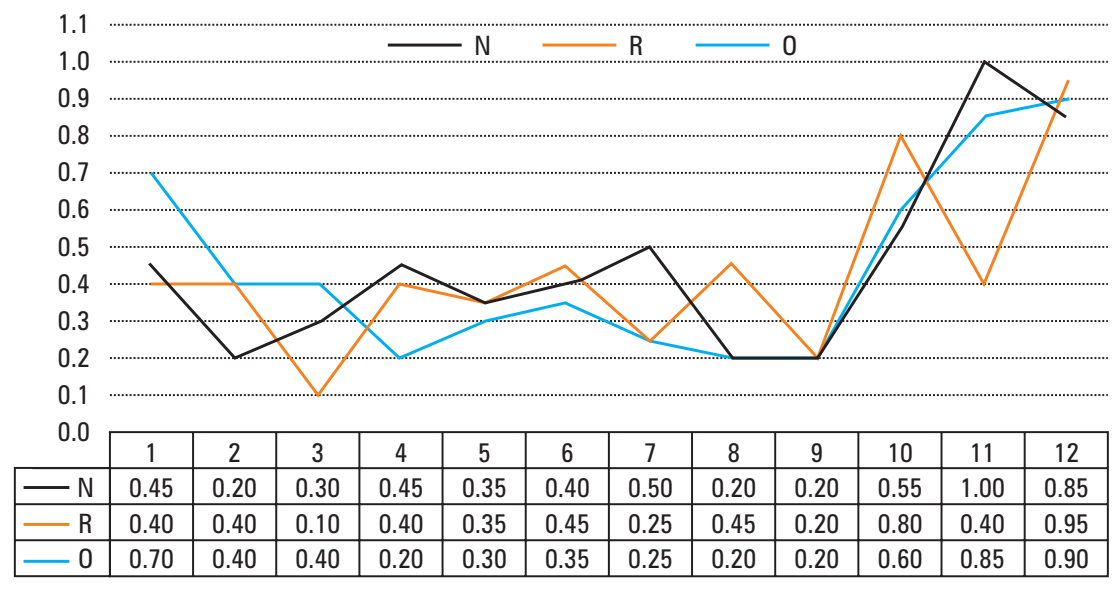

Fig. 9. Similarity ratio of land cover in evaluation polygons in the years 2006 and 2012

Based on the analysis of the land cover similarity coefficient in 2006 and in 2012, it can be concluded that in all three analysed areas, it is possible to detect changes in land cover in the evaluation polygons 3-9, which correspond to a distance of 4 to 18 $\mathrm{km}$ from the geometric centre of the layer's boundaries. In the case of the layers, which include the cities of Nitra and Olomouc, the smallest changes (or lack thereof) can be determined in outer evaluation polygons - that is, polygons 10, 11 and 12, which correspond to a distance from 18 to $24 \mathrm{~km}$ from the starting point of the analysis.

\section{Conclusions}

Spatial research with the use of GIS tools, applying the Corine Land Cover products made available through the Urban Atlas, facilitate a quick and insightful analysis of the possibility of determining changes in land cover. However, when making inferences, the accuracy of defining the boundaries and the changes in the surface sizes of land cover classes that characterize Corine Land Cover products must be taken into account. According to the Urban Atlas mapping guide [2006, 2012], the minimum mapping unit for class 1 and the land cover categories corresponding to this class is 0.25 ha, while for classes $2-5$ and the corresponding land cover categories, it is 1 ha. The correct selection of evaluation polygons is also an important factor for the accuracy of the analysis. In this work, the analysis was carried out in relation to the distance from the geometrical centre of the boundaries of the analysed layers, because this method particular was deemed the most effective. The method applied herein makes it possible to minimize the number of ring-shaped polygons used, by optimally fitting them into the boundaries of the analysed area.

The study shows that the concentration of land cover classes that can be included in the category of man-made investment (or developed) areas, in the cases of the area 
of the city of Nitra and that of the city of Radom occurs in zones 1 and 2, that is $0-2$ $\mathrm{km}$ and 2-4 km from the geometric centre of these areas, respectively. The analyses carried out in this work have shown that the ratio of the share of categories classified as investment areas to categories classified as biologically active areas decreases with the distance from the geometric centre of the given layer's boundaries. Based on the ratio of land cover similarity for the studied years, it was concluded that it is possible to determine the changes in land cover that occurred within 4 to $18 \mathrm{~km}$ from the geometrical centre of the analysed areas. However, in none of the three layers was there a significant change recorded in the ratio between the surface size of developed areas and biologically active areas categories between 2006 and 2012. It can therefore be concluded that the detected changes in land cover occurred either within the category of investment areas or within the category of biologically active areas, and thus there was no change in land cover from the biologically active areas category to the investment areas category.

This research was financed by the Ministry of Science and Higher Education of the Republic of Poland (BM-2305/KG/2018).

\section{References}

Antrop M. 1998. Landscape change: Plan or chaos. Landscape and Urban Planning, 41, 155-161. Bender O., Boehmer H.J., Jens D., Schumacher K.P. 2005. Using GIS to analyse long-term cultural landscape change in Southern Germany. Landsc. Urban Plan., 70, 111-125, 10.1016/j. landurbplan.2003.10.008.

Bičik I., Kupkova L., Jeleček L., Kabrda J., Štych P., Janoušek Z., Winklerova J. 2015. Land Use Changes in the Czech Republic 1845-2010. Socio-Economic Driving Forces, Springer Geography, Switzerland

Cegielska K., Kudas D., Różycka-Czas R., Salata T., Szylar M. 2017. The analysis of land cover macrostructure in the suburban area of Krakow. Geomatics, Landmanagement and Landscape, 2, 47-60, http://dx.doi.org/10.15576/GLL/2017.2.47.

Cegielska K., Noszczyk T., Kukulska A., Szylar M., Hernik J., Dixon-Gough R., Jombach S., Valánszki I., Filepné Kovács K. 2018. Land use and land cover changes in post-socialist countries: Some observations from Hungary and Poland. Land Use Policy, 78, 1-18, https:// doi.org/10.1016/j.landusepol.2018.06.017.

Cegielska K., Salata T., Gawroński K., Różycka-Czas R. 2017. Level of spatial differentiation of anthropogenic impact in Małopolska. J. Ecol. Eng., 8(1), 200-209, https://doi. org/10.12911/22998993/67100.

Degórski M. 2009. Krajobraz jako odbicie przyrodniczych i antropogenicznych procesów zachodzących w megasystemie środowiska geograficznego. Problemy Ekologii Krajobrazu, XXIII, 53-60.

Degórski M. 2016. Istota poznania procesów zachodzących w systemie środowiska glebowego dla interpretacji przemian krajobrazu. Problemy Ekologii Krajobrazu, XLI, 7-19.

Drzewiecki W. 2008. Monitoring zmian pokrycia i użytkowania terenu na podstawie wieloczasowych obrazów teledetekcyjnych. Roczn. Geomat., 6(3), 131-142.

Europejska Konwencja Krajobrazowa, sporządzona we Florencji dnia 20 października 2000 r. (Dz. U. z 2006 r. Nr 14, poz. 98). 
Halva J., Cyprich F. 2017. Land use changes from 1949 until present for cadastral area mechanice. Veda Mladých 2017. Science of Youth 2017 proceedings of reviewed contributions, Ráztočno, Slovakia, 24-30.

Lipský Z. 2000. Sledování zmeň v kulturní krajinĕ. ÚAE LF ČZU, Kostelec nad Černými Lessy.

Noszczyk T. 2018. Land Use Change Monitoring as a Task of Local Government Administration in Poland. Journal of Ecological Engineering, 19(1), 170-176. https://doi. org/10.12911/22998993/79409.

Pazúr R., Bolliger J. 2017. Land changes in Slovakia: Past processes and future directions. Applied Geography, 85, 163-175, https://doi.org/10.1016/j.apgeog.2017.05.009.

Rozporządzenie Ministra Spraw Wewnętrznych i Administracji z dnia 17 listopada 2011 r. w sprawie bazy danych obiektów topograficznych oraz bazy danych obiektów ogólnogeograficznych, a także standardowych opracowań kartograficznych (Dz. U. z 2011 r. Nr 279, poz. 1642).

Schulp C.J.E., Levers C., Kuemmerle T., Tieskens K.F., Verburg P.H. 2019. Mapping and modelling past and future land use change in Europe's cultural landscapes. Land Use Policy, https://doi.org/10.1016/j.landusepol.2018.04.030.

Staszewska S. 2012. Przekształcenia urbanistyczne osiedli wiejskich strefy podmiejskiej dużego miasta. Barometr Region., 4(30), 53-68.

Szewrański S., Kazak J., Sylla M., Świąder M. 2017. Spatial Data Analysis with the Use of ArcGIS and Tableau Systems. [In:] The Rise of Big Spatial Data. Lecture Notes in Geoinformation and Cartography. Eds. I. Ivan, A. Singleton, J. Horák, T. Inspektor. Springer.

Tokarczyk-Dorociak K., Kazak J., Szewrański S. 2018. The Impact of a Large City on Land Use in Suburban Area. The Case of Wrocław (Poland). Journal of Ecological Engineering, 19(2), 89-98, https://doi.org/10.12911/22998993/81783.

Urban Atlas 2018. https://land.copernicus.eu/local/urban-atlas (accessed:11.02.2019).

Urban Atlas 2006 mapping guide 2011. https:/land.copernicus.eu/user-corner/technical-library/urban-atlas-mapping-guide-2006 (accessed:11.02.2019).

Urban Atlas 2012 mapping guide v4.7 2016. https://land.copernicus.eu/user-corner/technicallibrary/urban-atlas-2012-mapping-guide-new (accessed: 11.02.2019).

Dr inż. Agnieszka Wnęk

Uniwersytet Rolniczy w Krakowie

Katedra Geodezji

30-198 Kraków, ul. Balicka 253a

e-mail: ag.wnek@urk.edu.pl

ORCID: https://orcid.org/0000-0001-8669-2519

Mgr inż. Dawid Kudas

Uniwersytet Rolniczy w Krakowie

Katedra Geodezji

30-198 Kraków, ul. Balicka 253a

e-mail: dawid.kudas@gmail.com

ORCID: https://orcid.org/0000-0003-1109-114X

Ing. Jozef Halva, PhD

Slovak University of Agriculture in Nitra

Department of Landscape Planning and Land Consolidation

Hospodárska 7, Nitra, Slovakia

e-mail: jozef.halva@uniag.sk 